\title{
The ciliate-copepod link in marine ecosystems
}

\author{
Albert Calbet* ${ }^{*}$ Enric Saiz \\ Institut de Ciències del Mar-CMIMA (CSIC), P. Marítim de la Barceloneta 37-49, Barcelona, Catalonia, Spain
}

\begin{abstract}
We show the results of a comparative, cross-ecosystem, analysis of the relative importance of ciliates as carbon sources for copepod, and, specifically, evaluated the strength of the ciliatecopepod trophic link. Although phytoplankton represent, globally, a far higher biomass than ciliates ( $>1$ order of magnitude), the consumption of the latter nevertheless comprises, on average, $30 \%$ of copepod daily carbon rations (ciliates + phytoplankton). The relative importance of ciliate consumption by copepods clearly depends on the trophic state of the system. In regions where phytoplankton concentrations are low $\left(<50 \mu \mathrm{gC}^{-1}\right)$, ciliate and phytoplankton contribution to the diet are equivalent. In richer environments this value declines, with ciliates accounting for only 25 and $22 \%$ of diet in environments characterized by phytoplankton concentrations of 50-500 and $>500 \mu \mathrm{gC} \mathrm{l}^{-1}$, respectively. From a biogeochemical point of view, our carbon budget estimates indicate that copepods process, on a global scale, 5.5 to 8.1 gigaton (Gt) phytoplankton-derived $\mathrm{C} \mathrm{yr}^{-1}$; from the heterotrophic side, this flux would represent 2.0 to 2.4 Gt ciliate-derived $\mathrm{C} \mathrm{yr}^{-1}$ and, probably, a higher value would be obtained if other microheterotrophs, like heterotrophic dinoflagellates, were included. Hence, the flux of carbon from ciliates, and other microzooplankton, towards upper trophic levels should definitely be considered in oceanic biogeochemical cycles and pelagic food web models.
\end{abstract}

KEY WORDS: Ciliates · Microzooplankton · Copepods · Mesozooplankton · Feeding · Biogeochemical cycles $\cdot$ Remineralization $\cdot$ Food webs $\cdot$ Marine

Resale or republication not permitted without written consent of the publisher

\section{INTRODUCTION}

The acknowledgement 2 decades ago of the importance of microbial processes in the functioning of planktonic systems challenged the traditional view of marine food webs (Pomeroy 1974, Azam et al. 1983). Microzooplankton appeared to be important structural and functional components of planktonic ecosystems, acting as top predators within microbial food webs (Sherr \& Sherr 2002, Calbet \& Landry 2004). Since most microbes are too small to be ingested by copepods, microzooplankton are considered as a trophic nexus between the microbial loop and the 'classical' food chain (Sherr et al. 1986, Gifford 1991). This intermediate role of microzooplankton is often claimed to explain the lack of relation between copepod production rates and phytoplankton abundance (e.g. Saiz et al. 1999, Calbet et al. 2002), and also to balance discrepancies between observed phytoplankton ingestion and copepod metabolic demands (Joint \& Williams 1985, Dam et al. 1993, 1995, Madsen et al. 2001).

The reported contribution of microzooplankton to copepod carbon ration is very variable, ranging from 0 to $100 \%$ of copepod ingestion (e.g. Sherr et al. 1986, Stoecker \& Capuzzo 1990, Gifford 1991, Sanders \& Wickham 1993, Broglio et al. 2004). The variability observed in the former estimates may result from differences in the nature of the ecosystems studied. From a conceptual point of view, it is expected that microzooplankton are mostly important to copepod diet in oligotrophic ecosystems, where autotrophic production is low and confined to small cells, rarely consumed by copepods (Nival \& Nival 1976, Berggreen et al. 1988, Dam et al. 1995, Calbet \& Landry 1999). However, this simplified view of the planktonic ecosystem is apparently not respected by copepods, which may exhibit a behaviorally driven feeding preference for microzooplankton (i.e. ciliates, heterotrophic dinofla- 
gellates) on many occasions (Fessenden \& Cowles 1994, Suzuki et al. 1999, Broglio et al. 2004). The motility of prey (Atkinson 1995, Rollwagen Bollens \& Penry 2003) and prey switching for the most abundant prey (Landry 1981, Kiørboe et al. 1996, Gismervik \& Andersen 1997) typically explain copepod positive selection of microzooplankton.

Even though the underlying mechanisms of the copepod preference for microzooplankton are not fully known, the relevant role of the microzooplanktoncopepod trophic link is unquestionable. However, this link is not usually considered in the construction of carbon budgets for marine ecosystems (but see Dam et al. 1995) or in ecosystem models of fisheries yield (Pauly \& Christensen 1995, Jackson et al. 2001, Pauly et al. 2002).

This situation called for an extensive examination of the microzooplankton-copepod interaction, to establish the relevance of this trophic path on a global scale, and to look for factors possibly shaping the relationship between these 2 important plankton groups. Our study focused on ciliates because data on copepod feeding on other microzooplanktonic groups are scarce. This is partially due to the fact that, traditionally, ciliates have been considered as the main representatives of microzooplankton when constructing plankton models (Sherr \& Sherr 1988). Moreover, in terms of biomass, ciliates also comprise a relevant group of microzooplankton on an oceanic scale (Verity \& Paffenhöfer 1996).

The objective of this work is not merely to describe the present data on ciliate-copepod interactions, or to extend previous reviews on the subject (e.g. Gifford 1991, Sanders \& Wickham 1993), but (1) to assess the importance of ciliates as a food source for copepods in marine ecosystems, and (2) to quantify the strength of the ciliate-copepod link from the point of view of biogeochemical fluxes in the pelagial. The results obtained in this study will be useful not only to implement our knowledge of the dynamics of planktonic food webs, but also to the parameterization of food web models.

\section{MATERIALS AND METHODS}

We searched the literature for copepod grazing rates on ciliates in marine ecosystems (Table 1). Most of the copepod grazing rates were derived from incubations of natural seawater. Studies not providing essential parameters, like ciliate abundance and size, etc., were excluded. The resulting data set considers 23 studies (170 data points), and includes reports on oceanic and coastal waters, extending from polar to tropical regions. The collected data set covers a representative suite of ecosystems, characterized by different trophic conditions, and should thus provide a realistic approximation of the subject. For comparative purposes, simultaneous data on grazing rates on phytoplankton (101 paired data points) were collected when available.

Log transformation was applied to ingestion rate and abundance data to stabilize variance and to attain homoscedasticity. A total of 7 negative or not significant grazing estimates ( $4 \%$ of data) found in the data set were corrected to +0.0001 (to allow transformation and avoid division by zero in calculations). The distribution of the variables after log transformation was checked with the Shapiro-Wilk test and proved to be normal in all cases $(p>0.07)$. Ordinary least-squares regression was used when error variance of $y$ was expected to be much larger than the error variance of $X$ (in general, rates vs. state variables). In regression analysis, residuals were checked to verify that, after log transformation, errors were additive and not multiplicative. When computing averages from percentage data, the arcsine transformation was applied.

\section{RESULTS}

Phytoplankton and ciliate concentrations in the surveyed studies differed by several orders of magnitude, ranging from 1.7 to $7119 \mu \mathrm{gC}_{\text {phyto }} \mathrm{l}^{-1}$ (geometric mean: $132.6 \mu \mathrm{gC}_{\text {phyto }} \mathrm{l}^{-1}$ ) and from 0.020 to $295 \mu \mathrm{gC}_{\text {ciliate }} \mathrm{l}^{-1}$ (geometric mean: $7.2 \mu \mathrm{gC}_{\text {ciliate }} \mathrm{l}^{-1}$ ), respectively. Fig. 1 shows the scatterplot of the paired ciliate and phytoplankton concentrations. Ciliate biomass was weakly, although significantly, correlated to phytoplankton biomass ( $r=0.37, p<0.001$, log-transformed data). Regarding the contribution of ciliates to total plankton, the proportion of ciliates was affected by the trophic status (characterized as different phytoplankton biomass) of the system studied. At phytoplankton concentrations below $50 \mathrm{\mu gC}_{\text {phyto }} \mathrm{l}^{-1}$ ciliates represented $21 \%$ of combined carbon biomass (ciliates + phytoplankton), but this proportion decreased to 9 and $2 \%$ at concentrations of $50-500$ and $>500 \mu \mathrm{gC}_{\text {phyto }} \mathrm{l}^{-1}$, respectively (significant differences among groups at the 0.05 significance level, 1-way ANOVA test and Tukey HSD posterior test on arcsine-transformed data).

Weight-specific ingestion rates on ciliates ranged from negligible to $2.0 \mu \mathrm{gC}_{\text {ciliate }} \mu \mathrm{gC}_{\text {copepod }}{ }^{-1} \mathrm{~d}^{-1}$ (Fig. 2), overall averaging $0.018 \mu \mathrm{gC}_{\text {ciliate }} \mu \mathrm{gC}_{\text {copepod }}{ }^{-1} \mathrm{~d}^{-1}$ (geometric mean $; \pm 1 \mathrm{SE}$ interval $=0.015$ to $0.021, \mathrm{n}=168$ ). The functional relationship between ciliate biomass and the corresponding copepod-specific ingestion rates (Fig. 2) followed a power function of slope $<1$ $(\mathrm{p}<0.001, t$-test), indicating that the relative number of ciliates removed by copepod grazing decreased with ciliate biomass. Some caution is required when interpreting such a relationship in field feeding experiments, under a range of other available potential prey, 
Table 1. Summary of the studies used in the data set with references to the groups of prey considered, the geographical area surveyed, and the copepod species considered. C: ciliates; P: phytoplankton; 1: a carbon to chlorophyll ratio of 50 was used; 2: copepod carbon weight from dry weight (DW) assuming a DW carbon content of $40 \%$; 3: copepod weight from Hirst \& Kiørboe (2002); 4: copepod weight from Uye (1982); 5: copepod weight from Saito \& Kotani (2000)

\begin{tabular}{|c|c|c|c|c|}
\hline Species & Prey type & Zone surveyed & Comments & Source \\
\hline Calanus spp. & \multirow[t]{4}{*}{$\mathrm{C}$} & \multirow[t]{4}{*}{ North west coast of Spain } & 1,2 & \multirow[t]{4}{*}{ Batten et al. (2001) } \\
\hline Acartia spp. & & & 1,2 & \\
\hline Centrophages chierchiae & & & 1,2 & \\
\hline Para-Pseudocalanus spp. & & & 1,2 & \\
\hline Centropages typicus & \multirow[t]{6}{*}{ C, P } & \multirow[t]{6}{*}{ NW Mediterranean coast } & & \multirow[t]{6}{*}{ Broglio et al. (2004) } \\
\hline Clausocalanus spp. & & & & \\
\hline Euterpina acutifrons & & & & \\
\hline Oithona spp. & & & & \\
\hline Paracalanus parvus & & & & \\
\hline Temora stylifera & & & & \\
\hline $\begin{array}{l}\text { Temora longicornis } \\
\text { Acartia clausi }\end{array}$ & $\mathrm{C}, \mathrm{P}$ & English Channel & & J. Dutz (unpubl.) \\
\hline Calanus pacificus & \multirow[t]{4}{*}{ C, P } & \multirow{4}{*}{ Oregon coastal waters } & 3 & \multirow{4}{*}{ Fessenden \& Cowles (1994) } \\
\hline Pseudocalanus sp. & & & 3 & \\
\hline Centropages abdominalis & & & 4 & \\
\hline Acartia longiremis & & & 3 & \\
\hline Acartia tonsa & $\mathrm{C}, \mathrm{P}$ & Terrebonne Bay, Louisiana & 3 & Gifford \& Dagg (1988) \\
\hline Calanus finmarchicus & $\mathrm{C}, \mathrm{P}$ & Norwegian Sea & & Irigoien et al. (1998) \\
\hline Calanus helgolandicus & $\mathrm{C}, \mathrm{P}$ & Norwegian Sea & 3 & $\mathrm{X}$. Irigoien (pers. comm.) \\
\hline Neocalanus flemingeri & \multirow[t]{4}{*}{$\mathrm{C}, \mathrm{P}$} & \multirow[t]{4}{*}{ Western subartic Pacific } & 2 & \multirow[t]{4}{*}{ Kobari et al. (2003) } \\
\hline Neocalanus cristatus & & & 2 & \\
\hline Neocalanus plumchrus & & & 2 & \\
\hline Eucalanus bungii & & & 5 & \\
\hline $\begin{array}{l}\text { Acartia bifilosa } \\
\text { Eurytemora affinis }\end{array}$ & C, P & Northern Baltic Sea & & Koski et al. (2002) \\
\hline Temora sp. & $\mathrm{C}, \mathrm{P}$ & North Sea & & M. Koski (unpubl.) \\
\hline Calanus finmarchicus CIV-V & $\mathrm{C}, \mathrm{P}$ & Tromsø & & M. Koski (unpubl.) \\
\hline Calanus finmarchicus & \multirow[t]{3}{*}{$\mathrm{C}, \mathrm{P}$} & \multirow[t]{3}{*}{ Disko Bay, West Greenland } & & \multirow[t]{3}{*}{ Levinsen et al. (2000) } \\
\hline Calanus glacialis & & & & \\
\hline Calanus hyperboreus & & & & \\
\hline Eurytemora affinis & $\mathrm{C}, \mathrm{P}$ & Chesapeake Bay & 3 & Merrel \& Stoecker (1998) \\
\hline Oithona similis & $\mathrm{C}$ & Buzzards Bay, Massachusetts & 4 & Nakamura \& Turner (1997) \\
\hline Calanus helgolandicus & $\mathrm{C}, \mathrm{P}$ & Bergen, Norway & 3 & Nejstgaard et al. (2001) \\
\hline Calanus finmarchicus & $\mathrm{C}$ & Bergen, Norway & 3 & Nejstgaard et al. (1997) \\
\hline Calanus finmarchicus & $\mathrm{C}, \mathrm{P}$ & Gulf of St. Lawrence & & Ohman \& Runge (1994) \\
\hline Acartia spp. & $\mathrm{C}, \mathrm{P}$ & San Francisco Bay & 3 & Rollwagen Bollens \& Penry (2003) \\
\hline Paracalanus sp. & $\mathrm{C}, \mathrm{P}$ & Seto Inland Sea (Japan) & 3 & Suzuki et al. (1999) \\
\hline Calanus spp. nauplii & $\mathrm{C}, \mathrm{P}$ & Disko Bay, West Greenland & & Turner et al. (2001) \\
\hline Acartia tonsa & \multirow[t]{5}{*}{$\mathrm{C}, \mathrm{P}$} & \multirow[t]{5}{*}{ Mejillones coast, Chile } & 3 & \multirow[t]{5}{*}{ Vargas \& González (2004) } \\
\hline Centropages brachiatus & & & 3 & \\
\hline Acartia tonsa & & & 3 & \\
\hline Paracalanus parvus & & & 3 & \\
\hline Oithona similis & & & 4 & \\
\hline Eucalanus pileatus & $\mathrm{C}, \mathrm{P}$ & North Cape Hatteras & & Verity \& Paffenhöfer (1996) \\
\hline $200-500 \mu \mathrm{m}$ copepods & \multirow[t]{3}{*}{$\mathrm{C}, \mathrm{P}$} & \multirow[t]{3}{*}{$\begin{array}{l}\text { New Zealand Subtropical } \\
\text { Frontal Zone }\end{array}$} & 2 & \multirow[t]{3}{*}{ Zeldis et al. (2002) } \\
\hline 500-1000 $\mu \mathrm{m}$ copepods & & & 2 & \\
\hline$>1000 \mu \mathrm{m}$ copepods & & & 2 & \\
\hline
\end{tabular}

because the $<1$ slope could be mediated not only by satiation at high ciliate concentrations, but by a switch to higher feeding on alternative prey (e.g. phytoplankton).
Table 2 summarizes the surveyed records of copepod ingestion rates on ciliates and the paired ingestion rates on phytoplankton. Ingestion rates on phytoplankton represented a higher daily food intake in produc- 
Table 2. Copepod weight-specific ingestion rate $\left(\mu \mathrm{gC}_{\text {prey }} \mu \mathrm{gC}_{\text {copepod }} \mathrm{d}^{-1}\right.$, geometric mean; mean \pm 1 SE range is shown in parentheses) on phytoplankton and ciliates as a function of the trophic status of the system studied (characterized by phytoplankton carbon concentration, $\mu \mathrm{gC}_{\text {phyto }} \mathrm{l}^{-1}$ ). Average contribution of ciliates to copepod daily food (as phytoplankton + ciliates) rations is also shown

\begin{tabular}{|lccc|}
\hline $\begin{array}{l}\text { Phytoplankton } \\
\text { carbon } \\
\text { conc. }\left(\mu \mathrm{C}^{-1}\right)\end{array}$ & $\begin{array}{c}\text { Weight-specific } \\
\text { ingestion rate on } \\
\text { phytoplankton }\end{array}$ & $\begin{array}{c}\text { Weight-specific } \\
\text { ingestion rate on } \\
\text { ciliates }\end{array}$ & $\begin{array}{c}\text { \% ciliate in } \\
\text { diet as C }\end{array}$ \\
\hline$<50$ & 0.021 & 0.016 & 49 \\
$50-500$ & $(0.014-0.032)$ & $(0.012-0.020)$ & 25 \\
& 0.125 & 0.029 & 22 \\
& $(0.087-0.179)$ & $(0.022-0.039)$ & 0.021 \\
& 0.118 & $(0.013-0.034)$ & 22 \\
\hline
\end{tabular}

tive areas $\left(50-500\right.$ and $\left.>500 \mu \mathrm{gC}_{\text {phyto }} \mathrm{l}^{-1}\right)$, whereas in poorer areas $\left(<50 \mu \mathrm{gC}_{\text {phyto }} \mathrm{l}^{-1}\right)$ ciliate and phytoplankton ingestion rates were similar. The contribution of ciliate carbon in the copepod diet (here considered as ciliates + phytoplankton) averaged $30 \%$, but increased with the degree of oligotrophy of the ecosystem (Table 2). The contribution of ciliates to copepod diet appeared disproportionately high with respect to their relative abundance (Fig. 3). No significant relationship was observed between the contribution of ciliates to diet (arcsine transformed) and copepod body weight (linear regression analysis, $\mathrm{p}>0.05$ ).

A multiple regression analysis was conducted on standardized data $[(\log (x)$-average $) / S D)]$ to assess the relative importance of ciliate concentration driving

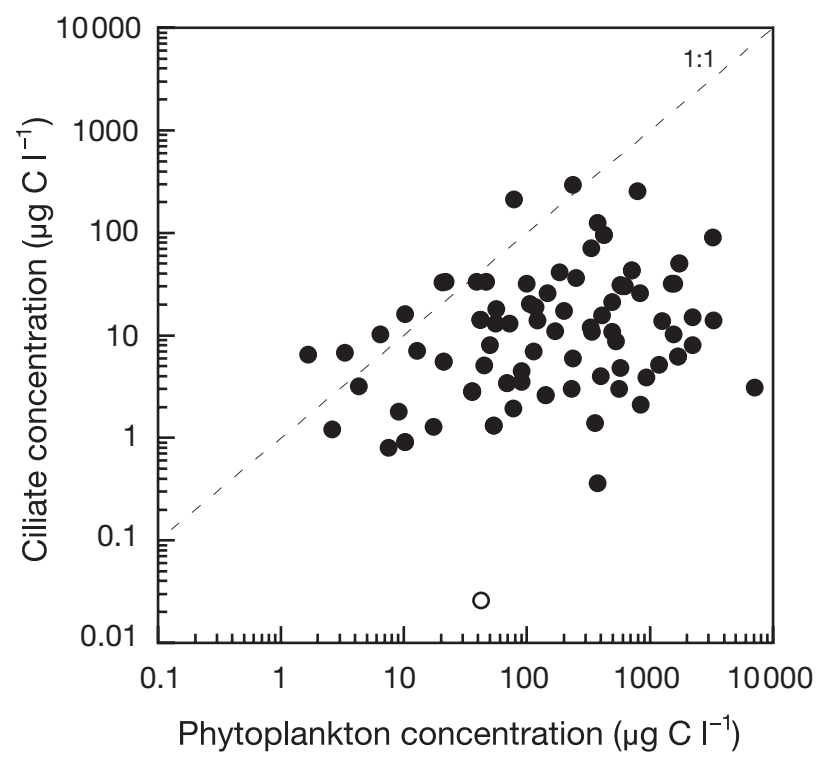

Fig. 1. Ciliate and phytoplankton concentrations $(\mathrm{n}=106)$. The 1:1 relationship is indicated by the dashed line. O: outlier falling outside the $1.5 \times$ interquartile range weight-specific copepod ingestion rates. Additional independent variables (phytoplankton concentration, individual copepod weight, and temperature) were also included in the model. The test of the model followed a backward step-wise procedure. Three outliers falling outside the $1.5 \times$ interquartile range were not used for the model. Temperature did not add any significant contribution, and the model based on the remaining independent variables explained $73 \%$ of the variance of copepod ingestion rates ( $p<0.0001)$. The relative strengths of the effects associated with each of these variables were directly compared using the standard partial regression coefficients $\left(\beta^{\prime}\right)$. Ciliates and phytoplankton contributed equally and positively to the model $\left(\beta_{\text {ciliate }}^{\prime}=+0.33\right.$, and $\beta^{\prime}{ }_{\text {phyto }}=$ +0.39 ), and copepod biomass had a strong negative weight $\left(\beta_{\text {bodymass }}^{\prime}=-0.69\right)$.

\section{DISCUSSION}

\section{Contribution of ciliates to copepod diet}

Ciliate biomass in the oceans is far lower than that of the dominating plant food (phytoplankton), and bounded by the 1:1 relationship, which suggests that there is a constraint in the maximum attainable biomass of ciliates the ecosystems can support. However, ciliates were identified as important components of the copepod diet, their contribution to copepod daily food rations being disproportionately high, independent of copepod body weight, and increasing inversely with the trophic status of the system. In oligotrophic ecosystems (most of the world's oceans) ciliate-associated carbon supply for copepods equals that of phytoplankton. Our study confirms, globally, the strength and relevance of the heterotrophic link between the microbial food webs and the classical food chain (Sherr et al. 1986). This derivation of energy and matter from the microbial loop, where regenerating processes are dominant, constitutes a significant export towards upper trophic levels.

The reasons for ciliate consumption by copepods have been widely discussed in the literature. Ciliates usually fall in the range of optimal prey sizes for copepods (Frost 1972, Berggreen et al. 1988), whereas many phytoplankton cells are too small (picoplankton) or too large (e.g. chain-forming diatoms). The use of bulk phytoplankton in our comparative study might, therefore, have biased determined selection patterns 


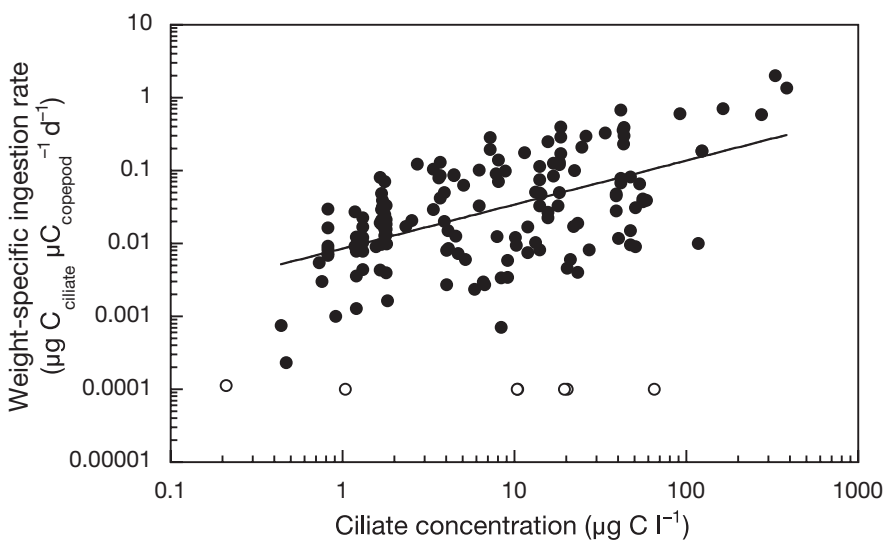

Fig. 2. Weight-specific ingestion rates of ciliates by copepods as a function of ciliate concentration. $\log y=a+b \log x$; $\mathrm{a}=-2.12 \pm 0.071 \mathrm{SE}, \mathrm{b}=0.60 \pm 0.072 \mathrm{SE}, \mathrm{r}^{2}=0.33, \mathrm{n}=149$. O: 11 outliers (not used for the equation) falling outside the $1.5 \times$ interquartile range

towards ciliates in environments dominated by either small (oligotrophic open-oceanic areas) or very large phytoplankton (nutrient-rich conditions). This could explain why the present study revealed that ciliates are, proportionately, ingested at higher rates in extremely rich systems $\left(>500 \mu \mathrm{gC}_{\text {phyto }} \mathrm{l}^{-1}\right)$, dominated by large-sized phytoplankton that are difficult to handle by copepods. However, at a local scale, along a seasonal cycle in an oligotrophic coastal area Broglio et al. (2004) also found, for a variety of species of copepods, a clear preference for ciliates with respect to $>5 \mu \mathrm{m}$ chlorophyll.

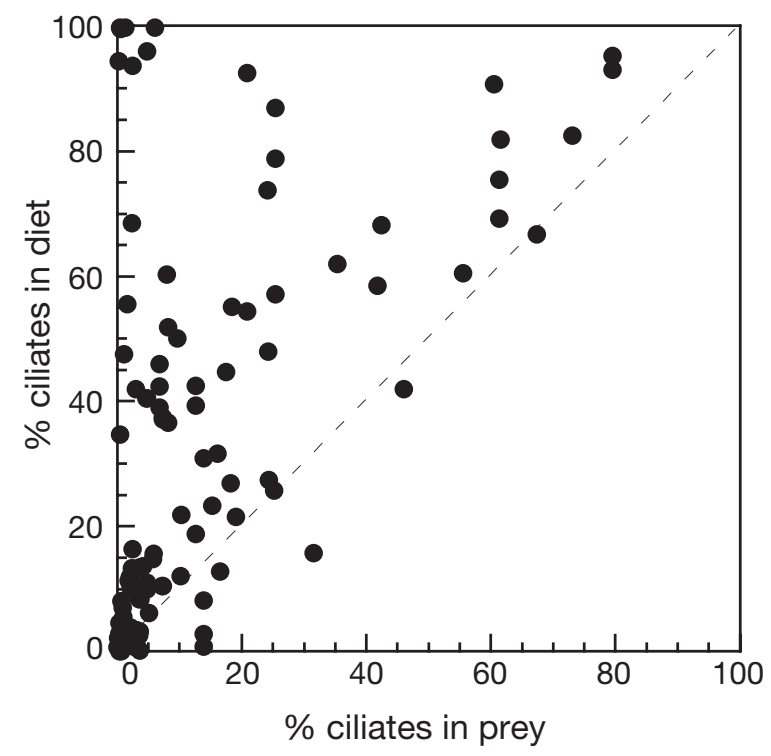

Fig. 3. Relative presence (in terms of carbon) of ciliates in the diet of copepods as a function of its relative availability in the water $(\mathrm{n}=109)$. Data above the (dashed) 1:1 line indicate spositive selection for ciliates
Food quality and encounter rates have been proposed as the most likely reasons for ciliate consumption (Jonsson \& Tiselius 1990, Stoecker \& Capuzzo 1990, Broglio et al. 2004). Ciliates have a higher nutritional value than algae, because their nitrogen content exceeds that of the primary producers (Stoecker \& Capuzzo 1990). Moreover, ciliates can also be employed as direct sources of proteins, amino acids, and important polyunsaturated fatty acids (PUFA), for the reproduction of crustaceans (Stoecker \& Capuzzo 1990, Wickham 1995, Broglio et al. 2003). In addition, the fast swimming of ciliates compared to phytoplankters favors higher clearance rates (1) because it increases their encounter rate with copepods, and (2) because their swimming generates a strong hydrodynamic signal that makes them easily detectably by the array of mechanoreceptors on the first copepod antennae (Jonsson \& Tiselius 1990, Atkinson 1995, Saiz \& Kiørboe 1995, Kiørboe et al. 1996, Kiørboe \& Visser 1999).

\section{Top-down control of ciliate populations}

The broad objective of this study was to seek general patterns and global estimates that would increase knowledge on the nature and consequences of the ciliate-copepod link. One obvious consequence of feeding on ciliates is the impact that copepods may have on this prey population. Scattered reports of copepod grazing impacts on ciliates found in the literature are highly variable, ranging from 0 to $200 \%$ of the standing stock consumed per day (Dolan 1991, Nielsen \& Kiørboe 1994, Lonsdale et al. 2000, Koski et al. 2002), probably reflecting the peculiarity of the system studied. It is, however, not possible to determine the global impact of copepod feeding on ciliate communities from the available data set, because most available literature considered did not provide results on copepod abundances. Nevertheless, we can calculate the amount of copepods needed to obtain a given impact on ciliates. Considering the global averages of ciliate abundance and copepod ingestion rates obtained in the present study, it would require 7 cope-

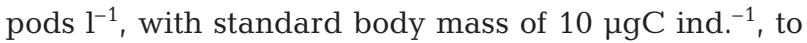
consume $50 \%$ of the ciliate standing stock. Such copepod abundances can be found in coastal productive waters or copepod swarms (Ambler 2002). To induce a similar impact on phytoplankton standing stock, 96 copepods $\mathrm{l}^{-1}$ would be needed, which is an unrealistic value for most marine ecosystems. It thus seems that the effects of copepod grazing on phytoplankton may be mostly mediated by their control on ciliate populations (cascade effects). We can also estimate the effects of copepod grazing on ciliate production from avail- 
able literature data on biomass, and the temperaturedependent equation for maximal ciliate growth rates obtained from Pérez et al. (1997, their Table 4): $\mu_{\max }=$ $0.37 \times \exp (0.061 \times t)$, where $\mu_{\max }$ is maximal ciliate growth rates $\left(\mathrm{d}^{-1}\right)$, and $t$ is temperature $\left({ }^{\circ} \mathrm{C}\right)$. Our calculations (not shown) indicate that 6 copepods $\mathrm{l}^{-1}$ would be needed to consume half of the daily ciliate production. Based on theses values copepods may only extensively influence ciliate abundance or production (topdown control) in coastal waters or productive systems characterized by high copepod biomass. Under other scenarios ciliate production and biomass might be regulated mainly by bottom-up mechanisms. These generalizations must be considered with caution because they describe global patterns, which possibly mask local variability (i.e. in particular ecosystems copepods may have a strong impact on phytoplankton or ciliates). Also, copepod and ciliate species inhabiting productive and oligotrophic environments may not be the same. Moreover, the generalizations ignore the existence of small-scale structures, like microlayers and small patches, which might result in higher impacts (Saiz et al. 1993). Furthermore, the above-mentioned estimates of top-down control are conservative because other potential ciliate grazers were not considered. Additional grazers representing a possible additional impact on ciliate communities include fish larvae, other planktonic crustaceans, other microzooplankters, etc. (see reviews of Pierce \& Turner 1992 and Sanders \& Wickham 1993).

Another aspect to consider, from the point of view of the ciliate, is that the impact of copepods may be reflected not only in changes in the stock or biomass. For instance, high copepod predation pressure may benefit species of ciliates with behavioral responses to avoid predation (e.g. Tontonia spp., Mesodinium spp., Dolan \& Pérez 2000). Therefore, it is possible that even if, as our study suggests, the copepod control of ciliate growth and standing stock in the oligotrophic oceans is usually low, they may affect ciliate community sizestructure and species composition.

\section{Global biogeochemical budgets}

Calculating general carbon budgets to be used in present and future predictive models formed an important goal of the present study. Copepods constitute the main food source for fish, and the quantification of the flux of matter through them has, therefore, traditionally been of interest to infer the potential yields of fisheries. From a biogeochemical point of view, and in relation to concerns of climate change, the role of zooplankton might have been underestimated. The magnitude of the carbon flux circulating through the cili- ate-copepod link at a global scale can be obtained by multiplying the weight-specific ingestion rates on ciliates by the standing stock of zooplankton biomass (assumed to be mainly copepods) in the world's oceans (estimated to be around 0.31 gigaton [Gt] $\mathrm{C}$ for the upper 100 m layer; Bogorov et al. 1968, Moiseev 1971). This approach is conservative, because small copepods have traditionally been severely undersampled due to the use of coarse net mesh sizes (Calbet et al. 2001, Gallienne \& Robins 2001) and because this value does not include the contribution of mesopelagic zooplankton either. Using our estimates of weight-specific ingestion rates (geometric mean $=0.018$ and $0.072 \mu \mathrm{gC}_{\text {prey }} \mu \mathrm{gC}_{\text {copepod }} \mathrm{d}^{-1}$ for ciliates and phytoplankton, respectively), copepods would consume at least 2.0 $\mathrm{GtC}_{\text {ciliate }} \mathrm{yr}^{-1}$, and about $8.1 \mathrm{GtC}_{\text {phyto }} \mathrm{yr}^{-1}$. These values are rough approximations since they are based on averaged estimates, and specific responses of ecosystems were not considered. A parallel estimation with a different approach and data set by Calbet (2001) rendered, however, similar values. This author reported the consumption of phytoplanktonic carbon by zooplankton at a global scale (taking into account oceanographic provinces) in the order of $5.5 \mathrm{GtC}_{\text {phyto }}$ $\mathrm{yr}^{-1}$. Applying the ciliate contribution to the copepod diet obtained in the present study $(30 \%$ in carbon terms) to the Calbet (2001) phytoplankton consumption data set, we infer that $30 \times 5.5 /(100-30)=$ $2.4 \mathrm{GtC}_{\text {ciliate }} \mathrm{yr}^{-1}$ should be circulating through the ciliate-copepod (actually, ciliate-zooplankton) link. Hence, independent approximations provided, in this case, rather similar values on zooplankton consumption of ciliates and phytoplankton. The omission of ciliates as one of the major components of copepod diet in these calculations would have resulted in a severe underestimation $(\sim 1 / 3$ in carbon terms, on average $)$ of the potential copepod yield.

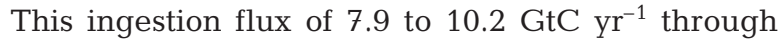
copepods due to combined grazing on ciliates and phytoplankton results in a flux of $\mathrm{CO}_{2}$, as respiratory

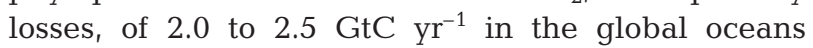
(assuming an average respiratory loss of $25 \%$; Bougis 1974, Kiørboe et al. 1985, Pagano et al. 1993). This

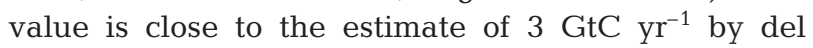
Giorgio \& Duarte (2002) based on the assumption that respiration by mesozooplankton would be equivalent to $5 \%$ of the combined microplankton respiration in the photic and thermocline waters.

How do these $\mathrm{C}$ fluxes relate to primary production? The ingestion of phytoplankton by copepods directly accounts for 12 to $18 \%$ of the global primary production (45 GtC $\mathrm{yr}^{-1}$; Falkowski et al. 1998). However, we must consider that a portion of primary production can indirectly reach copepods through the consumption of ciliates. For example, if we conservatively assume that 
ciliates feed mostly on phytoplankton (one single trophic step), and that their gross growth efficiency is $30 \%$ (Straile 1997), an equivalent of 19 to $21 \%$ of primary production should be at least assimilated and packed as ciliate biomass, and in final instance routed through the ciliate-copepod link. The combined feeding activity of zooplankton, either by direct (phytoplankton) or indirect (ciliate) consumption, yields an equivalent of 30 to $33 \%$ of the primary production reaching the zooplankton and, therefore, prone to arrive at upper trophic levels. Assuming ciliate and copepod prey size-spectra have little overlap (Jonsson 1986, Berggreen et al. 1988, Jakobsen \& Hansen 1997), these latter estimates support an efficient trophic transfer in planktonic food webs towards upper levels. This efficiency is further increased in unproductive regions of the oceans where mesozooplankton directly consume a proportionally higher fraction of the primary production (Calbet 2001) and where the contribution of heterotrophs to the copepod diet is maximal.

In terms of global biogeochemical budgets and primary production, nitrogen and phosphorus are key limiting elements. It is, therefore, interesting to evaluate whether copepods actually play a significant role in nutrient regeneration and if the flux mediated through microheterotroph consumption is relevant. We will limit such exercise to nitrogen, following a similar global analysis as above. Grazing activity by copepods in the oceans represents an estimated flux of 1.3 to 1.6 GtN yr ${ }^{-1}$, of which 0.4 to 0.5 and 0.8 to $1.2 \mathrm{GtN} \mathrm{yr}^{-1}$ would be supplied by ciliate and phytoplankton ingestion, respectively (weight C: $\mathrm{N}_{\text {ciliates }}=5.0$, Stoecker \& Capuzzo 1990, Gifford \& Caron 2000; and weight $\mathrm{C}: \mathrm{N}_{\text {algae }}=6.6$, Ho et al. 2003). Assuming that $20 \%$ of ingested nitrogen is excreted as ammonia (Kiørboe et al. 1985), nitrogen excretion by copepods (0.26 to $0.33 \mathrm{GtN} \mathrm{yr}^{-1}$ ) only provides 4 to $5 \%$ of the nitrogen requirements for primary production in the photic layer. This estimate is probably on the low side, because nonassimilated nitrogen, in the form of faecal pellets or sloppy feeding, may account for $40 \%$ of the copepod ingesta (assuming nitrogen assimilation efficiency to be $60 \%$; Kiørboe et al. 1985). Non-assimilated nitrogen would result in a flux of 0.8 to $1 \mathrm{GtN} \mathrm{yr}^{-1}$ in the oceans, which could eventually be remineralized by bacteria within the photic layer. All together, the sum of copepod excretion and remineralization of non-assimilated nitrogen could only explain $14 \%$ of the nitrogen requirements for primary production. Therefore, according to our analysis, the role of copepods in remineralization (and recycled production), globally, would appear of minor importance in contrast to previous considerations (Banse 1995). However, higher contributions to the $\mathrm{N}$ cycle at local scales cannot be ruled out (e.g. Alcaraz et al. 1994, Bode et al. 2004).

\section{Are our biogeochemical budgets conservative?}

The values presented here on the strength of the microzooplankton-copepod link are actually conservative. Below we detail 2 main considerations that would increase our budget estimates and that should be addressed in future studies.

First, ciliates are extremely fragile organisms and very sensitive to fixation (Sime-Ngando \& Groliere 1991, Leakey et al. 1994, Stoecker et al. 1994) and handling (Gifford 1985). Most of the studies considered have partially taken into account this matter. Lugol's acidic solution is accepted as one of the most benign preservatives (Stoecker et al. 1994) and, consequently, used as standard for experiments dealing with ciliates (90\% of the studies considered here used Lugol). Fixation with Lugol results in a significant shrinkage of the cell. When attempting to obtain biomass estimates, this reduction in cell size due to Lugol is usually passed by

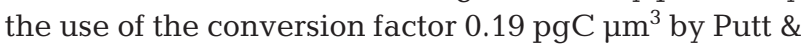
Stoecker (1989), which was based on shrunk, Lugolpreserved ciliates. However, it is quite likely that fixation, even with Lugol's at the recommended concentrations (Stoecker et al. 1994), may damage ciliates beyond recognition, thus reducing initial concentrations. These losses in cell numbers are not usually taken into account. The few studies that have addressed this issue have shown, quite consistently, that the losses of ciliates due to fixation are in the order of $20 \%$ for freshwater oligotrichs (Sime-Ngando et al. 1990), and 27-30\% for marine ciliates (Dale \& Burkill 1982, Broglio et al. 2004). Therefore, we could recalculate our data compensating for fixation-induced number losses (with the exception of those studies in which ciliate losses were originally accounted for). Applying a loss-factor of $30 \%$, the contribution of ciliates to copepod diet would rise to $34 \%$, and the carbon and nitrogen consumed on a global scale would increase to 2.6-2.8 and 0.5-0.6 GtC and $\mathrm{N} \mathrm{yr}^{-1}$, respectively. This correction is actually conservative because it does not consider ciliate damage due to handling (e.g. filtering through meshes may produce community losses up to $60 \%$; Gifford 1985, authors' pers. obs.). Unfortunately, it is difficult to correct for that until standard protocols for handling ciliates are developed and applied.

The second aspect to discuss regarding whether or not our estimates are conservative is that, as mentioned in the 'Introduction', we have focused our study on ciliates as representative of microzooplankton. However, other numerically important groups, such as heterotrophic dinoflagellates, may also play a significant role in copepod trophodynamics and may represent an important link from primary producers to higher trophic levels in certain ecosystems (Sherr \& Sherr 2002, Jeong et al. 2004). 
Table 3. Review of feeding rates of marine copepods on heterotrophic dinoflagellates (Hdino) in the literature. When available, the concentration of Hdino is also shown, as well as paired data on ciliate (Cil) concentration and copepod feeding rates on ciliates. Values in parentheses are SD

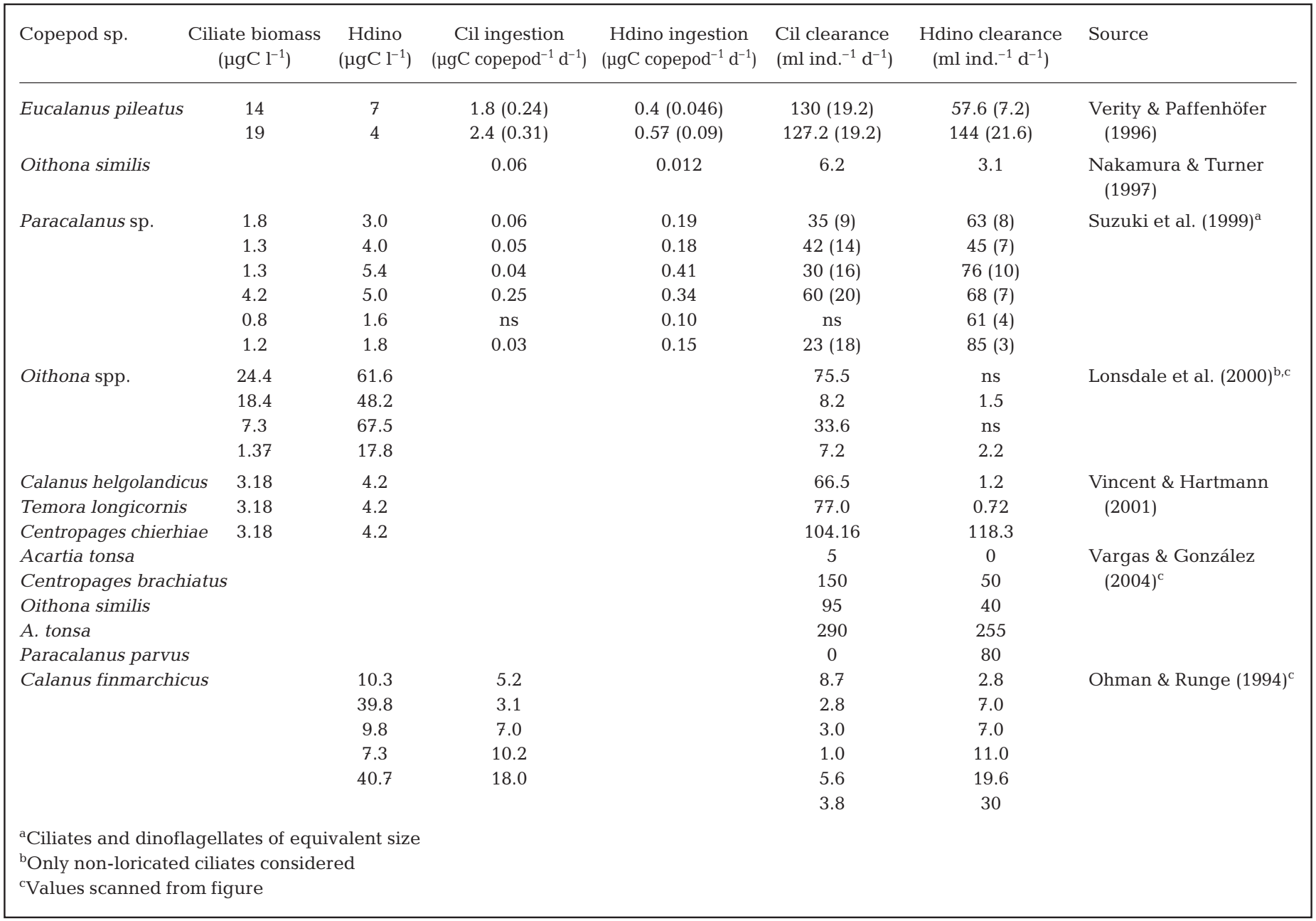

In our literature search, very few studies considered both ciliates and heterotrophic dinoflagellates as copepod prey. These studies, listed in Table 3, show that heterotrophic dinoflagellates are, in comparison to ciliates, similarly represented in plankton, and indicate that copepods clear them at rates comparable to those on ciliates (no significant differences between clearance rate on ciliates and heterotrophic dinoflagellates, paired $t$-test $\mathrm{p}>0.46$ ). Therefore, the few data available indicate that heterotrophic dinoflagellates may also contribute significantly to copepod diet, and our estimates of the importance of microzooplankton would probably be amplified if dinoflagellates were included.

In conclusion, our analysis fairly shows the notable strength of the copepod-ciliate (microzooplankton) link, especially in oligotrophic areas, evidencing the major importance of this trophic link, traditionally overlooked in plankton studies. Its inclusion results in a higher efficiency of biomass and energy transfer from primary producers to sustain the production of higher trophic levels (such as fish), especially in those systems where most primary producers are not available for direct copepod ingestion. Certainly, our comprehension of zooplankton dynamics and trophic interactions in marine planktonic environments would benefit from further contemplating this significant link.

Acknowledgements. We are indebted to the many colleagues who kindly provided their data and answered our questions about their studies. We are also grateful to M. Alcaraz and K. van Lenning for valuable comments on earlier drafts of the manuscript, and to H. Dam, G. McManus and the anonymous reviewers for their constructive criticism. This work was supported by projects ZOOTRANSFER (REN2001-1693) and PETROZOO (VEM2003-20037), and by program Ramón y Cajal from the Ministry of Science and Technology of Spain. We also acknowledge the OMEX grant (MAS3-CT97-0076) to S. Batten. 


\section{LITERATURE CITED}

Alcaraz M, Saiz E, Estrada M (1994) Excretion of ammonia by zooplankton and its potential contribution to nitrogen requirements for primary production in the Catalan Sea (NW Mediterranean). Mar Biol 119:69-76

Ambler JW (2002) Zooplankton swarms: characteristics, proximal cues and proposed advantages. Hydrobiologia 480:155-164

Atkinson A (1995) Omnivory and feeding selectivity in five copepod species during spring in the Bellingshausen Sea, Antarctica. ICES J Mar Sci 52:385-396

Azam F, Fenchel T, Field JG, Grey JS, Meyer-Reil LA, Thingstad F (1983) The ecological role of water-column microbes in the sea. Mar Ecol Prog Ser 10:257-263

Banse K (1995) Zooplankton: pivotal role in the control of ocean production. ICES J Mar Sci 52:265-277

Batten SD, Fileman ES, Halvorsen E (2001) The contribution of microzooplankton to the diet of mesozooplankton in an upwelling filament off the north west coast of Spain. Prog Oceanogr 51:385-398

Berggreen U, Hansen B, Kiørboe T (1988) Food size spectra ingestion and growth of the copepod Acartia tonsa during development: implications for determination of copepod production. Mar Biol 99:341-352

Bode A, Barquero S, González N, Alvarez-Ossorio MT, Varela M (2004) Contribution of heterotrophic plankton to nitrogen regeneration in the upwelling ecosystem of A Coruña (NW Spain). J Plankton Res 26:11-28

Bogorov VG, Vinogradov ME, Voronina NM, Kanaeva IP, Suetova IA (1968) Distribution of the zooplanktonic biomass in the surface layer of the ocean. Dokl Akad Nauk 182:1205-1208

Bougis P (1974) Ecologie du plancton marine, Vol II. Le Zooplancton. Masson et Cie, Paris

Broglio E, Jonasdottir SH, Calbet A, Jakobsen HH, Saiz E (2003) Effect of heterotrophic versus autotrophic food on feeding and reproduction of the calanoid copepod Acartia tonsa: relationship with prey fatty acid composition. Aquat Microb Ecol 31:267-278

Broglio E, Saiz E, Calbet A, Trepat I, Alcaraz M (2004) Trophic impact and prey selection by crustacean zooplankton on the microbial communities of an oligotrophic coastal area (NW Mediterranean). Aquat Microb Ecol 35:65-78

Calbet A (2001) Mesozooplankton grazing impact on primary production: a global comparative analysis. Limnol Oceanogr 46:1824-1830

Calbet A, Landry MR (1999) Mesozooplankton influences on the microbial food web: direct and indirect trophic interactions in the oligotrophic open ocean. Limnol Oceanogr 44: $1370-1380$

Calbet A, Landry MR (2004) Phytoplankton growth, microzooplankton grazing, and carbon cycling in marine systems. Limnol Oceanogr 49:51-57

Calbet A, Garrido S, Saiz E, Alcaraz M, Duarte CM (2001) Annual zooplankton succession in coastal NW Mediterranean waters: the importance of the smaller size fractions. J Plankton Res 23:319-331

Calbet A, Saiz E, Alcaraz M (2002) Copepod egg production in the NW Mediterranean: effects of winter environmental conditions. Mar Ecol Prog Ser 237:173-184

Dale T, Burkill PH (1982) 'Live counting' — a quick and simple technique for enumerating pelagic ciliates. Ann Inst Océanogr Paris 58:267-276

Dam HG, Miller CA, Jónasdóttir SH (1993) The trophic role of mesozooplankton at $47^{\circ} \mathrm{N}, 20^{\circ} \mathrm{W}$ during the North Atlantic Bloom Experiment. Deep-Sea Res II 40:197-212
Dam HG, Zhang X, Butler M, Roman MR (1995) Mesozooplankton grazing and metabolism at the equator in the central Pacific: implications for carbon and nitrogen fluxes. Deep-Sea Res II 42:735-756

del Giorgio PA, Duarte CM (2002) Respiration in the open ocean. Nature 420:379-384

Dolan JR (1991) Microphagous ciliates in mesohaline Chesapeake Bay waters: estimates of growth rates and consumption by copepods. Mar Biol 111:303-309

Dolan JR, Pérez MT (2000) Costs, benefits and characteristics of mixotrophy in marine oligotrichs. Freshw Biol 45: $227-238$

Falkowski PG, Barber RT, Smetacek V (1998) Biogeochemical controls and feedbacks on ocean primary production. Science 281:200-206

Fessenden L, Cowles TJ (1994) Copepod predation on phagotrophic ciliates in Oregon coastal waters. Mar Ecol Prog Ser 107:103-111

Frost BW (1972) Effects of size and concentration of food particles on the feeding behavior of the marine planktonic copepod Calanus pacificus. Limnol Oceanogr 17:805-815

Gallienne CP, Robins DB (2001) Is Oithona the most important copepod in the world's oceans? J Plankton Res 23: 1421-1432

Gifford DJ (1985) Laboratory culture of marine planktonic oligotrichs (Ciliophora, Oligotrichida). Mar Ecol Prog Ser 23:257-267

Gifford DJ (1991) The protozoan-metazoan trophic link in pelagic ecosystems. J Protozool 38:81-86

Gifford DJ, Caron DA (2000) Sampling, preservation, enumeration and biomass of marine protozooplankton. In: Harris RP, Wiebe PH, Lenz J, Skojdal HR, Huntley M (eds) ICES zooplankton methodology manual. Academic Press, San Diego, CA, p 193-221

Gifford DJ, Dagg MJ (1988) Feeding of the estuarine copepod Acartia tonsa Dana: carnivory vs. herbivory in natural microplankton assemblages. Bull Mar Sci 43:458-468

Gismervik I, Andersen T (1997) Prey switching by Acartia clausi: experimental evidence and implications of intraguild predation assessed by a model. Mar Ecol Prog Ser 157:247-259

Ho TY, Quigg A, Finkel ZV, Milligan AJ, Wyman $K$, Falkowski PG, Morel FMM (2003) The elemental composition of some marine phytoplankton. J Phycol 39: $1145-1159$

Irigoien X, Head R, Klenke U, Meyer Harris B, Harbour D, Niehoff B, Hirche HJ, Harris R (1998) A high frequency time series at weathership $M$, Norwegian Sea, during the 1997 spring bloom: feeding of adult female Calanus finmarchicus. Mar Ecol Prog Ser 172:127-137

Jackson JBC, Kirby MX, Berger WH, Bjorndal KA and 15 others (2001) Historical overfishing and the recent collapse of coastal ecosystems. Science 293:629-638

Jakobsen HH, Hansen PJ (1997) Prey size selection, grazing and growth response of the small heterotrophic dinoflagellate Gymnodinium sp. and the ciliate Balanion comatum - a comparative study. Mar Ecol Prog Ser 158:75-86

Jeong HJ, Yoo YD, Kim ST, Kang NS (2004) Feeding by the heterotrophic dinoflagellate Protoperidinium bipes on the diatom Skeletonema costatum. Aquat Microb Ecol 36: 171-179

Johnson MD, Rome M, Stoecker DK (2003) Microzooplankton grazing on Prorocentrum minimum and Karlodinium micrum in Chesapeake Bay. Limnol Oceanogr 48:238-248

Joint JR, Williams R (1985) Demands of the herbivore community on phytoplankton production in the Celtic Sea in August. Mar Biol 87:297-306 
Jonsson PR (1986) Particle size selection, feeding rates and growth dynamics of marine planktonic oligotrichous ciliates (Ciliophora: Oligotrichina). Mar Ecol Prog Ser 33: 265-277

Jonsson PR, Tiselius P (1990) Feeding behaviour, prey detection and capture efficiency of the copepod Acartia tonsa feeding on planktonic ciliates. Mar Ecol Prog Ser 60:35-44

Kiørboe T, Visser AW (1999) Predator and prey perception in copepods due to hydromechanical signals. Mar Ecol Prog Ser 179:81-95

Kiørboe T, Mohlenberg F, Hamburger K (1985) Bioenergetics of the planktonic copepod Acartia tonsa: relation between feeding, egg production and respiration and composition of specific dynamic action. Mar Ecol Prog Ser 26:85-97

Kiørboe T, Saiz E, Viitasalo M (1996) Prey switching behaviour in the planktonic copepod Acartia tonsa. Mar Ecol Prog Ser 143:65-75

Kobari T, Shinida A, Tsuda A (2003) Functional roles of interzonal migrating mesozooplankton in the western subartic Pacific. Prog Oceanogr 57:279-298

Koski M, Schmidt K, Engström-Öst J, Viitasalo M, Jónasdóttir S, Repka S, Sivonen K (2002) Calanoid copepods feed and produce eggs in the presence of toxic cyanobacteria Nodularia spumigena. Limnol Oceanogr 47:878-885

Landry MR (1981) Switching between herbivory and carnivory by the planktonic marine copepod Calanus pacificus. Mar Biol 65:77-82

Leakey RJG, Burkill PH, Sleigh MA (1994) A comparison of fixatives for the estimation of abundance and biovolume of planktonic ciliate populations. J Plankton Res 16:375-389

Levinsen H, Turner JT, Nielsen TG, Hansen BW (2000) On the trophic coupling between protists and copepods in arctic marine ecosystems. Mar Ecol Prog Ser 204:65-77

Lonsdale D, Caron DA, Dennett MR, Schaffner R (2000) Predation by Oithona spp. on protozooplankton in the Ross Sa, Antarctica. Deep-Sea Res II 47:3273-3283

Madsen SD, Nielsen TG, Hansen BW (2001) Annual population development and production by Calanus finmarchicus, C. glacialis and C. hyperboreus in Disko Bay, western Greenland. Mar Biol 139:75-93

Merrell JR, Stoecker DK (1998) Differential grazing on protozoan microplankton by developmental stages of the calanoid copepod Eurytemora affinis Poppe. J Plankton Res 20:289-304

Moiseev PA (1971) The living resources of the World Ocean. Israel Program for Scientific Translations, Jerusalem

Nakamura Y, Turner JT (1997) Predation and respiration by the small cyclopoid copepod Oithona similis: How important is feeding on ciliates and heterotrophic flagellates? J Plankton Res 19:1275-1288

Nejstgaard JC, Gismervik I, Solberg PT (1997) Feeding and reproduction by Calanus finmarchicus, and microzooplankton grazing during mesocosm blooms of diatoms and the coccolithophore Emiliania huxleyi. Mar Ecol Prog Ser 147:197-217

Nejstgaard JC, Naustvoll LJ, Sazhin A (2001) Correcting for underestimation of microzooplankton grazing in bottle incubation experiments with mesozooplankton. Mar Ecol Prog Ser 221:59-75

Nielsen TG, Kiørboe T (1994) Regulation of zooplankton biomass and production in a temperate, coastal ecosystem. 2. Ciliates. Limnol Oceanogr 39:508-519

Nival P, Nival S (1976) Particle retention efficiencies of an herbivorous copepod, Acartia clausi (adult and copepodite stages): effects of grazing. Limnol Oceanogr 21(1):24-38

Ohman MD, Runge JA (1994) Sustained fecundity when phytoplankton resources are in short supply: omnivory by
Calanus finmarchicus in the Gulf of St. Lawrence. Limnol Oceanogr 39:21-36

Pagano M, Gaudy R, Thibault D, Lochet F (1993) Vertical migrations and feeding rhythms of mesozooplanktonic organisms in the Rhone River plume area (North-West Mediterranean Sea). Estuar Coast Shelf Sci 37:251-269

Pauly D, Christensen V (1995) Primary production required to sustain global fisheries. Nature 374:255-257

Pauly D, Christensen V, Guénette S, Pitcher J, Sumaila UR, Walters CJ, Watson R, Zeller D (2002) Towards sustainability in world fisheries. Nature 418:689-695

Pérez MT, Dolan JR, Fukai E (1997) Planktonic oligotrich ciliates in the NW Mediterranean: growth rates and consumption by copepods. Mar Ecol Prog Ser 155:89-101

Pierce RW, Turner JT (1992) Ecology of planktonic ciliates in marine food webs. Aquat Sci 6:139-181

Pomeroy LR (1974) The Oceans' food web, a changing paradigm. BioScience 24:499-504

Putt M, Stoecker DK (1989) An experimentally determined carbon: volume ratio for marine 'oligotrichous' ciliates from estuarine and coastal waters. Limnol Oceanogr 34: 1097-1103

Rollwagen Bollens GC, Penry DL (2003) Feeding dynamics of Acartia spp. copepods in a large, temperate estuary (San Francisco Bay, CA). Mar Ecol Prog Ser 257:139-158

Saito H, Kotani Y (2000) Lipids of four boreal species of calanoid copepods: origin of monoene fats of marine animals at higher trophic levels in the grazing food chain in the subarctic ocean ecosystem. Mar Chem 71:69-82

Saiz E, Kiørboe T (1995) Predatory and suspension feeding of the copepod Acartia tonsa in turbulent environments. Mar Ecol Prog Ser 122:147-158

Saiz E, Tiselius P, Jonsson PR, Verity P, Paffenhöfer GA (1993) Experimental records of the effects of food patchiness and predation on egg production of Acartia tonsa. Limnol Oceanogr 38:280-289

Saiz E, Calbet A, Irigoien X, Alcaraz M (1999) Copepod egg production in the western Mediterranean: response to food availability in oligotrophic environments. Mar Ecol Prog Ser 187:179-189

Sanders RW, Wickham SA (1993) Planktonic protozoa and metazoa: predation, food quality and population control. Mar Microb Food Webs 7:197-223

Sherr E, Sherr B (1988) Role of microbes in pelagic food webs: a revised concept. Limnol Oceanogr 33:1225-1227

Sherr EB, Sherr BF (2002) Significance of predation by protists in aquatic microbial food webs. Antonie Leeuwenhoek Int J Gen Mol Microbiol 81:293-308

Sherr EB, Sherr BF, Paffenhöfer GA (1986) Phagotrophic protozoa as food for metazoans: a 'missing' trophic link in marine pelagic food webs? Mar Microb Food Webs 1:61-80

Sime-Ngando T, Groliere CA (1991) Effects quantitatifs des fixateurs sur la conservation des ciliés planctoniques d'eau douce. Arch Protinstenkd 140:109-120

Sime-Ngando T, Hartmann HJ, Groliere CA (1990) Rapid quantification of planktonic ciliates: comparison of improved live counting with other methods. Appl Environ Microbiol 56:2234-2242

Stoecker DK, Capuzzo JM (1990) Predation on Protozoa: its importance to zooplankton. J Plankton Res 12:891-908

Stoecker DK, Gifford DJ, Putt M (1994) Preservation of marine planktonic ciliates: losses and cell shrinkage during fixation. Mar Ecol Prog Ser 110:293-299

Straile D (1997) Gross growth efficiencies of protozoan and metazoan zooplankton and their dependence on food concentration, predator-prey weight ratio, and taxonomic group. Limnol Oceanogr 42:1375-1385 
Suzuki K, Nakamura Y, Hiromi J (1999) Feeding by the small calanoid copepod Paracalanus sp. on heterotrophic dinoflagellates and ciliates. Aquat Microb Ecol 17:99-103

Turner JT, Levinsen H, Nielsen TG, Hansen BW (2001) Zooplankton feeding ecology: grazing on phytoplankton and predation on protozoans by copepod and barnacle nauplii in Disk Bay, West Greenland. Mar Ecol Prog Ser 221: 209-219

Vargas CA, González HE (2004) Plankton community structure and carbon cycling in a coastal upwelling system. I. Bacteria, microprotozoans and phytoplankton in the diet of copepods and appendicularians. Aquat Microb Ecol 34: 151-164

Editorial responsibility: John Dolan, Villefranche-sur-Mer, France
Verity PG, Paffenhöfer GA (1996) On assessment of prey ingestion by copepods. J Plankton Res 18:1767-1779

Vincent D, Hartmann HJ (2001) Contribution of ciliated microprotozoans and dinoflagellates to the diet of three copepod species in the Bay of Biscay. Hydrobiologia 443: 193-204

Wickham SA (1995) Trophic relations between cyclopoid copepods and ciliated protists: complex interactions link the microbial and classic food webs. Limnol Oceanogr 40: $1173-1181$

Zeldis J, James MR, Grieve J, Richards L (2002) Omnivory by copepods in the New Zealand Subtropical Frontal Zone. J Plankton Res 24:9-23

Submitted: October 8, 2004; Accepted: December 6, 2004 Proofs received from author: February 1, 2005 